\title{
Freshwater fish diversity in three tributary streams in Serayu Basin, Central Java, Indonesia
}

\author{
SUHESTRI SURYANINGSIH`, DIAN BHAGAWATI, SRI SUKMANINGRUM, SUGIHARTO, \\ I.G.A. AYU RATNA PUSPITASARI \\ Faculty of Biology, Universitas Jenderal Soedirman. Jl. Dr. Soeparno No.6, Purwokerto Utara, Banyumas 53122, Central Java, Indonesia \\ Tel./fax.: +62-281-638794, `email: hestri.bio@gmail.com
}

Manuscript received: 7 October 2020. Revision accepted: 27 November 2020

\begin{abstract}
Suryaningsih S, Bhagawati D, Sukmaningrum S, Sugiharto, Puspitasari IGAAR. 2020. Freshwater fish diversity in three tributary streams in Serayu Basin, Central Java, Indonesia. Biodiversitas 21: 5811-5817. Determining the diversity of freshwater fish species in Central Java, Indonesia has been confounded by temporal and spatial limitations in past studies. The Serayu Basin is a large watershed in Central Java that is believed to have high freshwater fish diversity. We aimed to determine the diversity and community structure of freshwater fish species in three tributaries of the Serayu, elucidate the factors influencing this diversity, and determine the extent to which these tributaries contribute to the total freshwater fish species richness for southwest Central Java. We conducted gill net sampling from May to August 2018 on the Tulis, Mrawu, and Kali Sapi Rivers located at Banjanegara district Sampling followed a random group technique in upstream, midstream, and downstream river sections of each tributary. In total, we observed 21 freshwater fish species. Broadly, fish species diversity was relatively low in the study area, and water temperature and dissolved oxygen were important in maintaining fish diversity. These three tributaries house $27-46 \%$ of the freshwater fish species reported for southern Central Java.
\end{abstract}

Keywords: Banjarnegara, dissolved oxygen, diversity, fish, Serayu basin, species richness

\section{INTRODUCTION}

The Serayu River is one of the major rivers in Central Java, Indonesia. It is $153 \mathrm{~km}$ in length, stretching from Wonosobo District to Cilacap District, and is fed by 14 (Krismono et al. 2009) tributaries Major tributaries in Banjarnegara District include the Tulis, Mrawu, and Kali Sapi Rivers, all of which are subject to different land-use types. Understanding fish diversity and population dynamics in the Serayu's tributaries is vital because these smaller rivers play a crucial role in its overall diversity. The diversity of fish species in large rivers is closely related to the diversity of fish in the tributaries that support it (Pander and Geist, 2018; Essien Bok and Isemin 2020). Tributaries can be critical habitats for fish as the aquatic habitat is their habitat and low habitat quality in mainstem rivers (Stegmann et al. 2019). Assessments of freshwater fish richness in the Serayu suggest that richness varies spatially, with some areas having fewer than 30 species. For example, 13 species were reported from upstream areas in Wonosobo (Haryono et al. 2014), 18 species from the Klawing River (Suryaningsih et al. 2018).

The diversity of freshwater fish species is strongly influenced by environmental factors (Beesley and Prince 2010), such as temperature (Mondal and Bat 2020) and environmental factors. Certain factors such as $\mathrm{pH}$, dissolved oxygen, and water velocity were found to significantly predict richness and diversity. Increase in stream depth and width offers more space for individuals and provides more variation in niches, resulting in higher diversity in accordance with species-area relationship. Fish species richness within a river is affected by habitat heterogeneity and other habitat parameters (Jenkins and Jupiter 2011; Huang et al. 2019). Among these, water quality, substrate type, and pollutant burdens can affect the presence of a given species (Lakra et al. 2010), because different species occupy different niches and vary in their environmental tolerances (Costa et al. 2013; Hasyimah et al. 2013; Basavaraja et al. 2014; Ohee 2016). Even within a single river, habitat availability or quality may differ to the extent that there are differences in diversity among the upstream, midstream, and downstream reaches (Guo et al. 2018).

Recent research from several rivers in Java, especially Central Java, has been conducted. (Haryono et al. 2014) reported that in the upstream area of Serayu Wonosobo, 13 fish species were found whereas Suryaningsih et al. (2018) found 18 fish species in the Klawing river. Nuryanto et al. (2012) found 22 fish species of fish in the Cileumeuh river, 19 fish species were discovered in the Cikawung river (Nuryanto et al. 2015); and in the Cijalu river, 19 fish species were identified (Nuryanto et al. 2016). Based on the results of previous research studies, the diversity of fish species in southern part of Central Java varies significantly with some areas having fewer than 30 species. Past research efforts have provided a reasonable estimate of fish species and their distributions within tributaries of the Serayu watershed. Here, we aimed to determine species diversity in three major tributaries and the environmental factors supporting species richness. 


\section{MATERIALS AND METHODS}

\section{Study area}

Our study took place in the upper reaches of the Serayu watershed in three major tributaries in Banjarnegara District, Indonesia: The Tulis, Mrawu, and Kali Sapi Rivers. We sampled at three locations in each river: upstream, midstream, and downstream (Figure 1). Habitat descriptions for each of the nine sampling locations are provided in Table 1 .
Field sampling of fish and environmental parameters

Fish samples were collected using gillnets of a 0.5 -inch and 1-inch mesh size, $30 \mathrm{~m}$ length of net Samples were collected monthly from June to September 2018 during a 12-h sampling event, gill net was setting start at afternoon until morning. which was replicated four times at each sampling location. Fresh samples were transported on ice to a laboratory, where they were washed in running water, placed in a $10 \%$ formalin solution for fixation for 48 hours, and then transferred to $70 \%$ ethyl alcohol for storage. Specimens were identified based on Kottelat et al. (2013). (Tan and Armbruster 2018).

Table 1. Habitat descriptions for nine sampling locations on three tributaries of the Serayu River in Central Java, Indonesia

\begin{tabular}{|c|c|c|c|}
\hline Habitat characteristic & Upstream (1) & Midstream (2) & Downstream (3) \\
\hline \multicolumn{4}{|l|}{ Tulis } \\
\hline Location & $7^{\circ} 24^{\prime} 35^{\prime \prime} \mathrm{S} 109^{\circ} 15^{\prime} 15.6^{\prime \prime} \mathrm{E}$ & $7^{\circ} 22^{\prime} 2.9^{\prime \prime} \mathrm{S} 109^{\circ} 15^{\prime} 15.6^{\prime \prime} \mathrm{E}$ & $7^{\circ} 23 ' 27.5^{\prime \prime} \mathrm{S} 109^{\circ} 45^{\prime} 004^{\prime \prime} \mathrm{E}$ \\
\hline Elevation (m asl) & 506 & 460 & 407 \\
\hline Depth $(\mathrm{m})$ & 65 & 66 & 45 \\
\hline Width (m) & 30 & 30 & 30 \\
\hline Substrate type & Big stones, gravel & Medium and small stones, sand & Medium and small stones, sand \\
\hline \multicolumn{4}{|l|}{ Mrawu } \\
\hline Location & $7^{\circ} 29^{\prime} 18.5^{\prime \prime} \mathrm{S} 109^{\circ} 28^{\prime} 41$ "E & $7^{\circ} 22^{\prime} 10.5^{\prime \prime} \mathrm{S} 109^{\circ} 41^{\prime} 35.1^{\prime \prime} \mathrm{E}$ & 7 48'478" S 109 47'133"E \\
\hline Elevation (m asl) & 453 & 430 & 382 \\
\hline Depth $(\mathrm{m})$ & 60 & 84 & 92 \\
\hline Width (m) & 40 & 40 & 45 \\
\hline Substrate type & Big stones & Big stones, sand & Medium and small stones, sand \\
\hline \multicolumn{4}{|l|}{ Kali Sapi } \\
\hline Location & $7^{\circ} 29^{\prime} 18.5^{\prime \prime} \mathrm{S} 109^{\circ} 28^{\prime} 41 " \mathrm{E}$ & $7^{\circ} 22^{\prime} 10.5^{\prime \prime} \mathrm{S} 109^{\circ} 41^{\prime} 35.1^{\prime \prime} \mathrm{E}$ & $7^{\circ} 48^{\prime} 478^{\prime \prime} \mathrm{S} 109^{\circ} 47^{\prime} 133^{\prime \prime E}$ \\
\hline Elevation (m asl) & 257 & 227 & 207 \\
\hline Depth (m) & 55 & 65 & 85 \\
\hline Width (m) & 30 & 28 & 30 \\
\hline Substrate type & Small stone, sand & Gravel, sand, mud & Mud \\
\hline
\end{tabular}

Note: Sands: <4mm in diameter, Gravel: $4-37.5 \mathrm{~mm}$ in diameter, Small stones: 3.75-7.5 $\mathrm{cm}$ in diameter, Medium stones: $75-20 \mathrm{~cm}$ in diameter, Big/large stones: $>20 \mathrm{~cm}$ in diameter
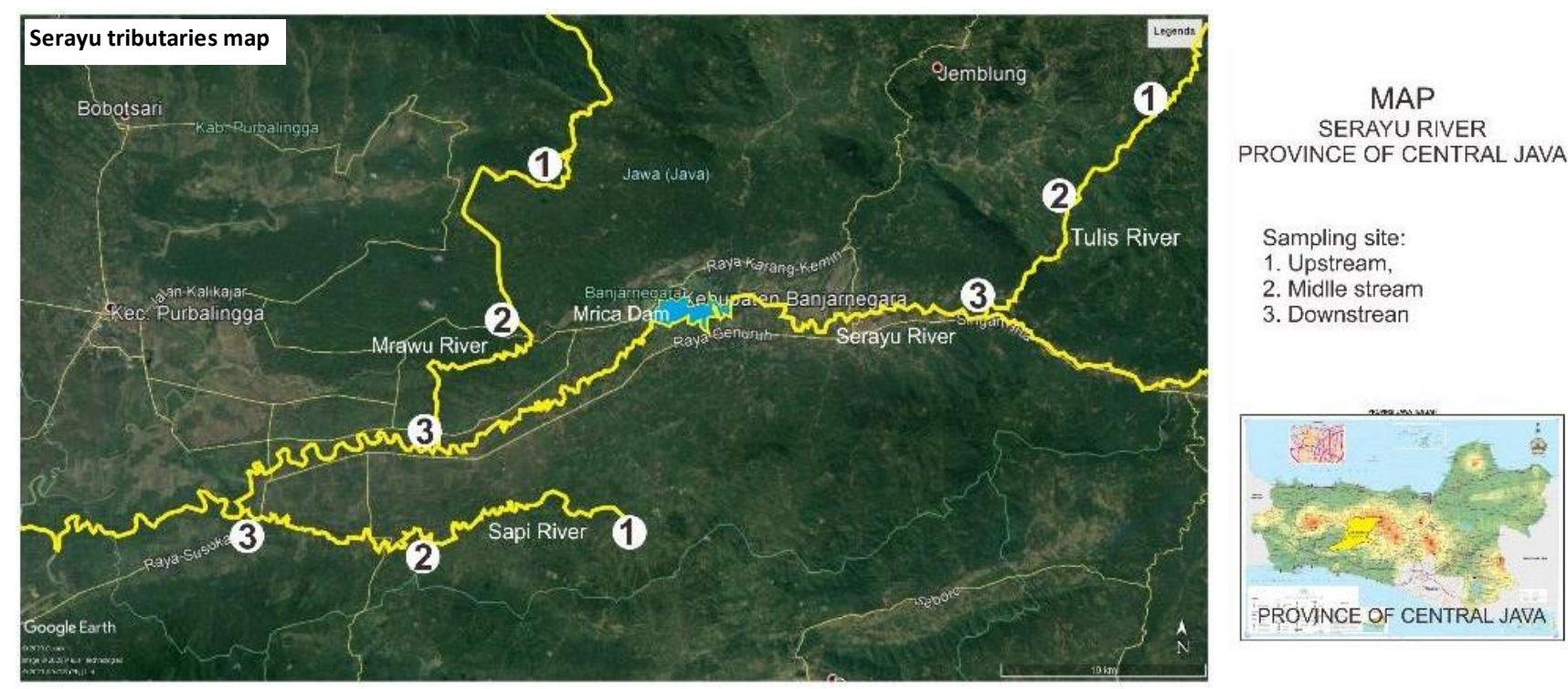
Sampling site:
1. Upstream,
2. Midlle stream
3. Downstrean

Figure 1. Study area map of the Serayu River and three of its tributaries in Banjarnegara District, Central Java, Indonesia, i.e. Tulis, Mrawu and Kali Sapi rivers. Three sampling locations were established in each tributary, shown as 1, 2, and 3 on the map 
The physiochemical parameters measured at each site included river width, substrate type, water depth, temperature, brightness, flow velocity, $\mathrm{pH}$, dissolved oxygen, and dissolved carbon dioxide (Table 2). At upstream sampling locations, the river bank zone was dominated by plantation forest with a substrate of large and medium-sized stones (Sand/sands, diameter $<4 \mathrm{~mm}$, Gravel/Gravel, 4-37.5 mm diameter, Small stones 3.75-7.5 $\mathrm{cm}$, Medium stones $75-20 \mathrm{~cm}$, Big/large stones $>20 \mathrm{~cm}$ ) Midstream riverbank zones were dominated by open areas, rice fields, and human settlements with a substrate of medium-sized rock and gravel. Land-use types in the river bank zone of downstream sampling locations included open areas, rice fields, sand mining, and human settlements, with a riverbed substrate of gravel, sand, and mud.

\section{Statistical analyses}

The average number of individuals, species abundance, diversity, evenness, and dominance were compared among sampling locations and month using two-way analysis of variance with posthoc Fisher's least significant difference tests in SPSS ver. 23 (IBM Corp., Armonk, NY, USA). Species diversity was estimated using the Shannon-Weiner diversity index ( $\left.\mathrm{H}^{\prime}\right)$ (Magurran 2004):

$$
\mathrm{H}^{s}=\sum_{i=1}^{g} p i \ln p i
$$

Evenness (E) was calculated by dividing Shannon's diversity by the logarithm of the number of species:

$$
E=\frac{H s}{\ln \xi}
$$

Species dominance was expressed as the Simpson index $(\mathrm{D}=1-\mathrm{S})$;

$$
\mathrm{D}=\sum(p i)^{2}=\sum\left(\frac{n i}{N}\right)^{2}
$$

All indices were calculated using the statistical software BioDiversity Pro (McAleece et al. 1997).

\section{RESULTS AND DISCUSSION}

\section{Species richness among the three tributaries}

We collected 574 fish specimens belonging to 21 species in ten families over the survey period (June-August 2018). Of these, 106 individuals of 14 species in five families were collected from the Tulis River, 238 individuals of 13 species in six families were collected from the Mrawu River, and 230 individuals of 16 species in eight families were collected from the Kali Sapi River (Table 3, Figure 2).

Among the three tributaries, the Kali Sapi River had the highest species richness and abundance (16 species, 230 individuals, followed by the Mrawu River (13 species, 238 individuals) and the Tulis river (14 species, 106 individuals). $\mathrm{H}^{\prime}$ was greatest in the Tulis River $\left(\mathrm{H}^{\prime}=\right.$ $2.384)$, followed by the Kali Sapi $\left(\mathrm{H}^{\prime}=1.916\right)$ and the Mrawu $\left(\mathrm{H}^{\prime}=1.545\right)$ (Table 3). These differences in richness and abundance are likely due to environmental conditions.

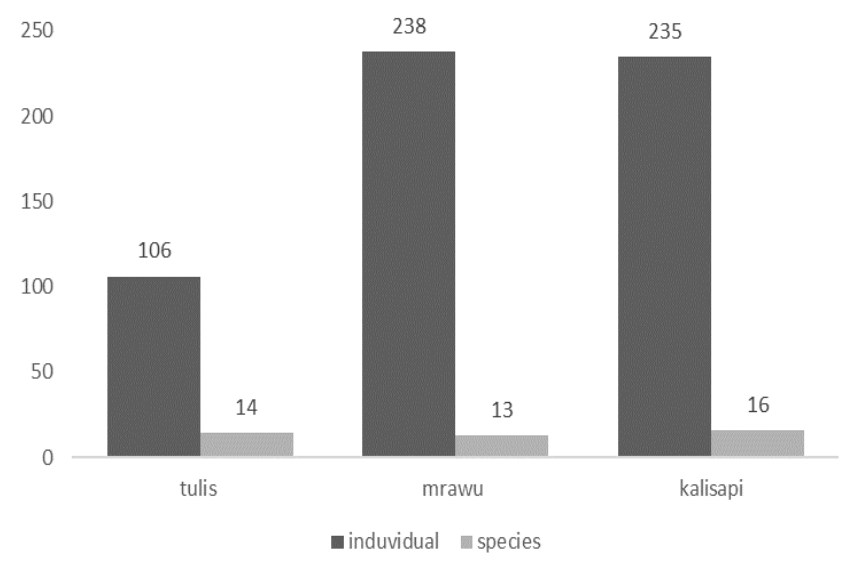

Figure 2. Species richness and abundance of freshwater fish in

\begin{tabular}{|c|c|c|c|c|c|c|c|c|c|}
\hline \multirow{2}{*}{ River } & \multicolumn{3}{|c|}{ Tulis } & \multicolumn{3}{|c|}{ Mrawu } & \multicolumn{3}{|c|}{ Kali Sapi } \\
\hline & US & MS & DS & US & MS & DS & US & MS & DS \\
\hline Water temperature $\left({ }^{\circ} \mathrm{C}\right)$ & 25.1 & 27.5 & 25.5 & 24.3 & 23.6 & 24.7 & 27.7 & 27.7 & 28.9 \\
\hline Air temperature $\left({ }^{\circ} \mathrm{C}\right)$ & 35 & 32 & 33 & 28 & 28 & 32 & 32 & 32 & 32 \\
\hline Humidity (\%) & 43 & 53 & 44 & 68 & 74 & & 68 & 68 & 57 \\
\hline velocity (m/det) & 1.66 & 8.3 & 0.55 & 1.43 & 0.93 & 0.58 & 1.15 & 0.85 & 0.7 \\
\hline Depth of visibility $(\mathrm{cm})$ & 45 & 43 & 40 & 45 & 50 & 10 & 28 & 22 & 25 \\
\hline Acidity $(\mathrm{pH})$ & 7 & & 7 & 7.5 & 7 & 7 & 7 & 7 & 6,8 \\
\hline $\mathrm{DO}(\mathrm{mg} / \mathrm{L})$ & 9.45 & 9.5 & 9.7 & 7.8 & 7.65 & 7.45 & 7.3 & 7.6 & 7,5 \\
\hline $\mathrm{CO} 2(\mathrm{mg} / \mathrm{L})$ & 0 & 0 & 0 & 0 & 0 & 0 & 0.77 & 0 & 0 \\
\hline $\mathrm{BOD}(\mathrm{mg} / \mathrm{L})$ & 3.2 & 3.12 & 3.66 & 2.1 & 2.86 & 3.48 & 4.4 & 4.28 & 5.06 \\
\hline $\mathrm{COD}(\mathrm{mg} / \mathrm{L})$ & 140 & 104 & 66 & 30 & 12 & 54 & 78 & 62 & 52 \\
\hline
\end{tabular}
three tributary rivers in Central Java, Indonesia

Table 2. Environmental condition of the sampling sites 
Table 3. Species richness, abundance, and distribution of freshwater fish in the Tulis, Mrawu, and Kali Sapi Rivers, Central Java, Indonesia

\begin{tabular}{|c|c|c|c|c|c|c|c|}
\hline Family & Species & Tulis & Mrawu & Kali Sapi & Total & $\begin{array}{c}\text { Percentage } \\
(\%)\end{array}$ & $\begin{array}{l}\text { Distribution (No. of } \\
\text { rivers that present) }\end{array}$ \\
\hline \multirow[t]{10}{*}{ Cyprinidae } & Systomus rubripinnis & 25 & 6 & 101 & 132 & 22.99 & 3 \\
\hline & Hampala macrolepidota & 9 & 14 & 11 & 34 & 5.9 & 3 \\
\hline & Barbonymus gonionotus & 7 & 0 & 9 & 16 & 2.7 & 2 \\
\hline & Osteochilus microcephalus & 15 & 0 & 40 & 55 & 9.5 & 2 \\
\hline & Osteochilus vittata & 5 & 35 & 21 & 61 & 10.06 & 3 \\
\hline & Rasbora lateristriata & 0 & 1 & 2 & 3 & 0.52 & 2 \\
\hline & Rasbora argyrotaenia & 6 & 8 & 1 & 15 & 2.6 & 3 \\
\hline & Rasbora aprotaenia & 2 & 1 & 0 & 3 & 0.52 & 2 \\
\hline & Tor tambra & 5 & 3 & 0 & 8 & 1.39 & 2 \\
\hline & Labiobarbus kuhlii & 8 & 0 & 0 & 8 & 1.39 & 1 \\
\hline \multirow[t]{2}{*}{ Bagridae } & Mystus nigriceps & 4 & 0 & 9 & 13 & 2.2 & 2 \\
\hline & Hemibagrus nemurus & 3 & 5 & 11 & 19 & 3.33 & 3 \\
\hline \multirow[t]{2}{*}{ Cichlidae } & Oreochromis niloticus & 7 & 3 & 2 & 12 & 2.09 & 3 \\
\hline & Oreochromis mossambicus & 0 & 7 & 8 & 15 & 2.6 & 2 \\
\hline Clariidae & Clarias gariepinus & 0 & 17 & 0 & 17 & 2.9 & 1 \\
\hline Sisoridae & Glyptothorax platypogon & 0 & 2 & 0 & 2 & 0.3 & 1 \\
\hline Osprhonemidae & Trichopodus trichopterus & 9 & 0 & 2 & 11 & 1.91 & 2 \\
\hline Mastacembelidae & Macrognathus aculeatus & 0 & 0 & 2 & 2 & 0.3 & 1 \\
\hline Channidae & Channa striata & 1 & 0 & 8 & 9 & 1.56 & 2 \\
\hline Nemacheilidae & Nemacheilus fasciatus & 0 & 136 & 2 & 138 & 24.04 & 2 \\
\hline Siluridae & Ompok hypophthalmus & 0 & 0 & 1 & 1 & 0.17 & 1 \\
\hline \multicolumn{2}{|l|}{ No. of individuals } & 106 & 238 & 230 & 574 & & \\
\hline \multicolumn{2}{|l|}{ No. of species } & 14 & 13 & 16 & & & \\
\hline \multicolumn{2}{|c|}{$\%$ of total species richness } & 57 & 61 & 76 & & & \\
\hline
\end{tabular}

Correlation analyses indicated that water temperature and dissolved oxygen had a strong influence on fish diversity and distribution in all three tributaries $\left(\mathrm{R}^{2}=0.70\right.$ for water temperature and $\mathrm{R}^{2}=0.78$ for dissolved oxygen). Other measured physiochemical parameters did not show significant influences on fish distributions. These results are comparable to those of Basavaraja et al. (2014) and Yagci et al. (2016). Nuryanto et al. (2016) suggested that differences in species distribution patterns are a result of differences in environmental conditions among rivers, particularly dissolved oxygen, free carbon dioxide, $\mathrm{pH}$, and substrate. However, Nsor and Ubaday (2016) found that nitrogen and phosphorus had a strong influence on the occurrence of freshwater fish species in rivers.

Bray-Curtis similarity cluster analysis indicated that the Tulis River shared a more similar fish species community with the Kali Sapi than with the Mrawu (Figure 3).

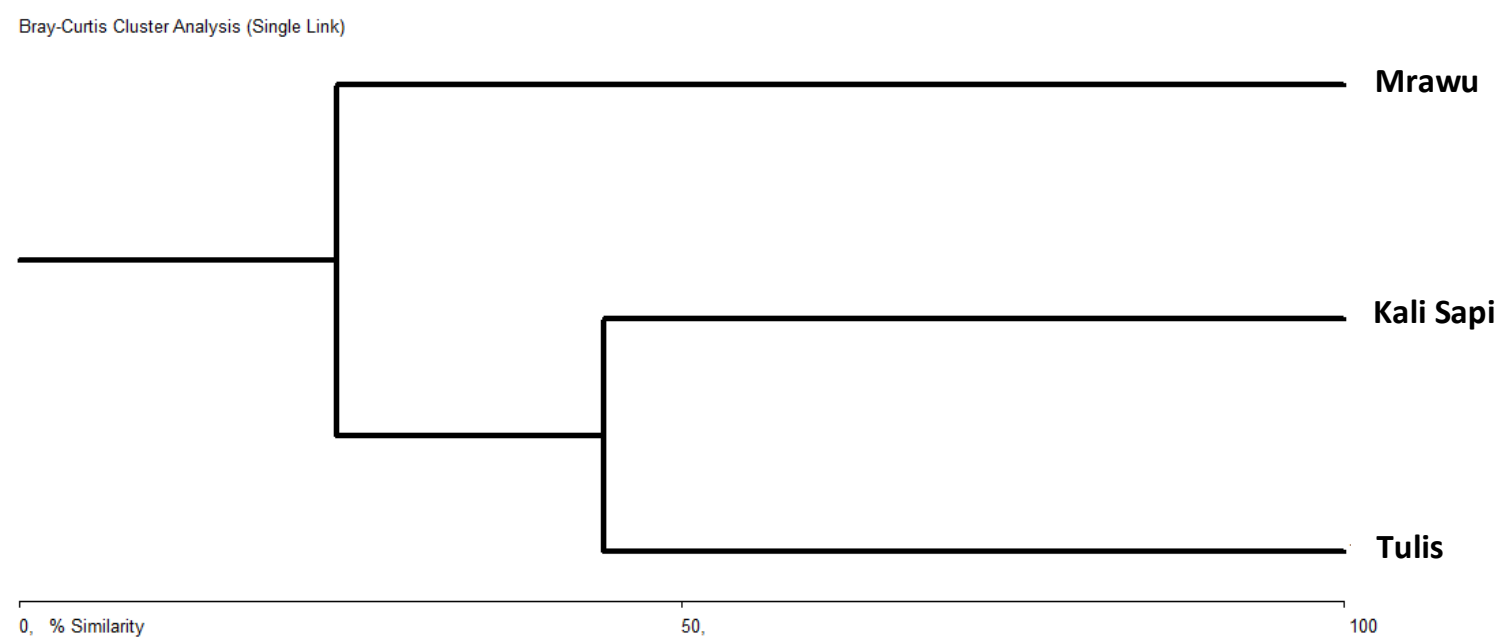

Figure 3. Dendrogram representing similarity in fish species composition among three tributaries based on a Bray-Curtis cluster analysis 
Huang et al. (2019) found that the environmental parameters of elevation, velocity, conductivity, and river depth and width influenced the distribution and abundance of freshwater fish species, whereas water temperature, dissolved oxygen, and substrate size were less important. This is likely a product of species niche, wherein species selected for environmental cues that meet their biological or life-history needs. Keller et al. (2018) identified four fish habitat guilds that were predictors of fish diversity; these guilds were determined by river depth, velocity, and structural complexity. The apparent similarity in fish species composition between the Tulis and Kali Sapi Rivers may be related to riverbank conditions; both rivers have forested banks (plantation forest) in their upper reaches. Lo et al. (2020) suggested that forest condition influences the composition of fish species in rivers passing through forested areas. In addition, river velocity and width are important determinants of fish species diversity in rivers (Mondal and Bat 2020). These factors were less influential in our study, likely because the three tributaries considered here were relatively similar in both width and depth (Table 1).

All three tributaries were dominated by one or two species. In the Tulis and Kali Sapi Rivers, Systomus rubripinnis was the dominant species, accounting for $23 \%$ and $43.9 \%$ of all captured individuals respectively, whereas Nemacheilus fasciatus was the dominant species in the Mrawu (57\% of all captured individuals. This discovery may be caused by a lack of suitable habitat, particularly with respect to the river velocity, the clarity of the water, and the type of substrate (Ridho et al. 2019.; Mondal and Bat 2020).

\section{Within-river variation in species richness}

In a river, the species richness varies, in the Tulis river the highest species richness is in the midstream followed by the upstream and the lowest is in the downstream. In the Mrawu river, the number of species is the same between the midstream and the upstream and only slightly decreases in the downstream, while in the Kali Sapi river the highest species are in the midstream and the lowest is in the upstream (Table 1). The results of statistical tests between river sections in the Tulis and Mrawu rivers were not significantly different (P2.8 F> 0.05). This pattern of different species richness was found in the Kali Sapi river $(\mathrm{P} 2.8 \mathrm{~F}>0.05)$. This result is probably due to the habitat conditions in the Tulis and Mrawu rivers which are almost the same, namely the rocky bottom substrate. Whereas in the Kali Sapi river, the mud substrate and the downstream part of the river are deeper than the two rivers. According to Jenkins and Jupiter (2011) and Huang et al. (2019), Fish species richness within a river is affected by habitat heterogeneity, especially substrate type, because different species occupy different niches and vary in their environmental tolerance (Costa et al. 2013; Hasyimah et al. 2013; Basavaraja et al. 2014; Ohee 2016). Even within a single river, habitat availability or quality may differ to the extent that there are differences in diversity among the upstream, midstream, and downstream reaches (Guo et al. 2018). Within river, species richness was $\mathrm{H}^{\prime}$ also varied within each river system; in the Tulis River it was highest at the midstream sampling location, followed by the upstream and downstream locations, and in the Mrawu and Kali Sapi Rivers it was highest midstream, followed by downstream and upstream locations (Table 4). Fish distributions within the tributaries followed a similar pattern, with the highest richness and abundance at midstream locations, followed by downstream and upstream (Table 4). This pattern was correlated with river depth $\left(\mathrm{R}^{2}=0.67\right)$ and substrate type. Freshwater fish diversity depends on substrate types, because substrate types provide the prerequisite micro-conditions and can be viewed as an indicator of stream habitat quality. Substrate coarseness and heterogeneity, representing substrate size and microhabitat diversity, may substantially influence stream fish assemblages (Amour et al. 2011; Li et al. 2016). These results echo those of Huang et al. (2019) and $\mathrm{Hu}$ et al. (2019), who found that variation in the richness and abundance of freshwater fish was related to elevation and river depth and width.

Table 4. Diversity parameters in the three tributaries

\begin{tabular}{lccc}
\hline \multicolumn{1}{c}{ Parameter } & Mrawu & Tulis & Kali Sapi \\
\hline Species richness $(\mathrm{S})$ & 13 & 14 & 16 \\
No. of individuals & 238 & 106 & 230 \\
Dominance (D) & 0.3602 & 0.1148 & 0.2419 \\
Shannon $\left(\mathrm{H}^{\prime}\right)$ & 1,545 & 2,384 & 1,916 \\
Simpson $(1-\mathrm{D})$ & 0.6398 & 0.8852 & 0.7581 \\
Evenness $\left(\mathrm{e}^{\wedge} \mathrm{H} / \mathrm{S}\right)$ & 0.3606 & 0.7751 & 0.4245 \\
Equitability $(\mathrm{J})$ & 0.6023 & 0.9035 & 0.691 \\
\hline
\end{tabular}

Table 5. Diversity parameters for each sampling location $(n=9)$ within three tributaries. US, MS, and DS refer to upstream, midstream, and downstream sampling locations, respectively

\begin{tabular}{lccccccccc}
\hline \multirow{2}{*}{ Diversity parameter } & \multicolumn{3}{c}{ Tulis } & \multicolumn{3}{c}{ Mrawu } & \multicolumn{3}{c}{ Kali Sapi } \\
\cline { 2 - 10 } & US & MS & DS & US & MS & DS & US & MS & DS \\
\hline Species richness (S) & 9 & 11 & 6 & 9 & 9 & 8 & 6 & 15 & 10 \\
No. of individuals & 27 & 50 & 28 & 86 & 103 & 46 & 44 & 114 & 72 \\
Dominance (D) & 0.1413 & 0.1136 & 0.2602 & 0.5687 & 0.4984 & 0.2297 & 0.2438 & 0.2561 & 0.2612 \\
Shannon $\left(\mathrm{H}^{\prime}\right)$ & 2.067 & 2.272 & 1.517 & 1.021 & 1.727 & 1.135 & 1.6 & 1.905 & 1.679 \\
Simpson $(1-\mathrm{D})$ & 0.8587 & 0.8864 & 0.7398 & 0.4313 & 0.5016 & 0.7703 & 0.7562 & 0.7439 & 0.7388 \\
Evenness $\left(\mathrm{e}^{\wedge} \mathrm{H} / \mathrm{S}\right)$ & 0.8777 & 0.882 & 0.76 & 0.3083 & 0.3458 & 0.7026 & 0.8256 & 0.4477 & 0.5362 \\
\hline
\end{tabular}


Only six species were found in all three rivers: Systomus rubripinnis, Hampala macrolepidota, Osteochilus vittata, Rasbora argyrotaenia, Hemibagrus nemurus, and Oreochromis niloticus. Cyprinidae was the most diverse family, with ten recorded species across all rivers, followed by Bagridae and Cichlidae with two species respectively, and Clariidae, Sisoridae, Osphronemidae, Mastacembelidae, Channidae, and Siluridae, with one species, respectively. The prevalence of Cyprinidae is related to the life-history traits that characterise this family; its members often have wide environmental niches and are widely distributed, especially in low-oxygen environments (Das et al.2012; Petsut et al. 2017). In addition, Cyprinidae is the most abundant fish family worldwide, with 1,058 reported species (Paujiah et al. 2019).

Six species were found in two of the tributaries: Barbonymus gonionotus, Osteochilus microcephalus, Rasbora lateristriata, Rasbora aprotaenia, Tor tambra (Cyprinidae), and Mystus nigriceps. Mystus nigriceps is typically found in large, slow-flowing rivers with turbid water and a muddy substrate. Species only observed in one tributary included Labiobarbus kuhlii (Tulis River), Clarias gariepinus (Mrawu River), (introduced African catfish), (Glyptothorax platypogon). Glyptothorax platypogon is known to occur in the upstream zone of the Serayu River. This species has the distinctive characteristic of using a thoracic adhesive apparatus to secure itself in its torrential river habitat (Lestari et al. 2018.; Haryono 2014).

Broadly, the diversity of freshwater fish observed in the three tributaries was relatively low. Water temperature and dissolved oxygen were important factors influencing this diversity. The fish species observed in the tributaries considered here account for $27-46 \%$ of the total number of species reported for southern Central Java.

Based on the result, it can be concluded that small tributaries can support the diversity of Serayu river freshwater fish diversity.

\section{ACKNOWLEDGEMENTS}

We are grateful to the Dean of the Faculty of Biology at the University of, Jenderal Soedirman, for his support in securing funding for this research. We extend our gratitude to our colleagues who assisted in field data collection. This research was supported by a Directorate General of Higher Education Research Fellowship and funding from the Universitas Jenderal Soedirman, Purwokerto, Central Java, Indonesia.

\section{REFERENCES}

Amour BA, Bosclair D, Dray S, Legender P. 2011. Relationships between species feeding traits and environmental conditions in fish communities: a three-matrix approach. Ecol Appl 21 (2): 363-377.

Basavaraja D, Narayana J, Kiran BR, Puttaiah ET. 2014. Fish diversity and abundance in relation to water quality of Anjanapura reservoir, Karnataka, India. Intl J Curr Microbiol Appl Sci 3 (3): 747-757.
Beesley LS, Prince J. 2010. Fish community structure in an intermittent river: the importance of environmental stability, landscape factors and within-pool habitat descriptors. Mar Freshw Res 61 (5): 605-614. DOI: 10.1071/MF09137.

Costa MR, Mattos TM, Borges JL, Araujo FG. 2013. Habitat preferences of common native fishes in a tropical river in Southeastern Brazil. Neotrop Ichthyol 11 (4): 871-880.

Das KM, Naskar M, Mondal ML, Srivastava PK, Dey S, Rej, A. 2012. Influence of ecological factors on the patterns of fish species richness in tropical Indian rivers. Acta Ichthyologica et Piscatoria 42 (1): 47 58.

Essien-Ibok MA, Isemin NL. 2020. Fish species diversity, abundance and distribution in the major water bodies in Akwa Ibom State, Nigeria. Biodivers Intl J 4 (1): 42-48. DOI: 10.15406/bij.2020.04.00163.

Guo Q, Liu X, Ao X, Qin J, Wu X, Ouyang S. 2018. Fish diversity in the middle and lower reaches of the Ganjiang River of China: Threats and conservation. PLoS ONE 13 (11): e0205116. DOI: 10.1371/journal.pone.0205116.

Hu M, Wang C, Liu Y, Jia S. 2019. Fish species composition, distribution and community structure in the lower reaches of Ganjiang River, Jiangxi, China. Sci Rep 9: 10100. DOI: 10.1038/s41598-019-466002 .

Hasyimah NR, Syakira MH, Mohd Syahril MZ, Samat A, Iwana I. 2013. Water quality, diversity and distribution of freshwater fishes in Negeri Sembilan. J Acad 3: 10-19.

Huang J, Huang L, Yuanin M, Naicheng W. 2019. Correlation of fish assemblages with habitat and environmental variables in a headwater stream section of Lijiang River, China. Sustainability 11: 1135. DOI: 10.3390/su.11041135.

Jenkins AP, Jupiter SD. 2011. Spatial and seasonal patterns in freshwater ichthyofaunal communities of a tropical high island in Fiji. Environ Biol Fish 91 (3): 261-274. DOI: 10.1007/s10641-011-9776-4.

Keller K, Allsop Q, Brim-Box J, Buckle D, Crook DA, Douglas MM, Kennard MJ, Luiz OJ, Pusey BJ, Townsend SA, King AJ. 2019. Dry season habitat use of Fishes in an Australian tropical river. Sci Rep 9: 5677. DOI: 10.1038/s41598-019-41287-x.

Konan KF, Edia OE, Bony KY, Kouamé KM, Gourène G. 2014. Fish diversity and assemblages according to distance from source along a coastal river gradient (Ehania River; south-east of Ivory Coast). Iranian J Fish Sci 14 (1): 112-129.

Kottelat M. 2013. The fishes of the inland waters of southeast Asia: A catalogue and core bibliography of the fishes known to occur in freshwaters, mangroves and estuaries. Raffles Bull Zool 27: 1-663.

Krismono, Hedianto DA, Zahid A, Rahardjo MF. 2009. Biolimnologi sungai Serayu Sebagai dasar Pengelolaan. Prosiding Forum Nasional Pemulihan dan Konservasi Sumber Daya Ikan IV, Jakarta. [Indonesian]

Lakra WS, Kumar RS, Kumar V, Kumar DU, Pandey Sa, Gusain OP. 2010. Fish diversity, habitat ecology and their conservation and management issues of a tropical River in Ganga basin, India. Environmentalist 30 (4): 306-319. DOI: 10.1007/s10669-010-9277-6.

Lestari W, Zayyana DA, Setyaningrum N, Amelia T. 2018. The guild composition for modelling fish community in Banjaran River, Purwokerto. Biosaintifika 10 (3): 698-705.

Li X, Li YR, Zhu R, Wang LZ, Yan YZ, Influences of local habitat, tributary position, and dam characteristics on fish assemblages within impoundments of low-head dams in the tributaries of the Qingyi River, China. Zool Res 37 (2): 67-74.

Lo M, Reed J, Castello J, Steel EA, Frimpong EA, Ickowitz A. 2020. The influence of forests on freshwater fish in the tropics: A systematic review. BioScience 70 (5): 1-11. DOI: 10.1093/biosci/biaa021.

Margurran AE. 2004. Measuring Biological Diversity. Blackwell Publishing, Oxford.

McAleece N, Lambshead PJD, Paterson GLJ. 1997. Biodiversity Pro. The Natural History Museum, London.

Mondal R, Bhat A. 2020. Temporal and Environmental drivers of fishcommunity structure in tropical streams from two contrasting regions in India. PLoS ONE 15 (4): e227354. DOI: 10.1371/journal.pone.02273541.

Nsor CA, Obodai EA. 2016. Environmental determinants influencing fish community structure and diversity in two distinct seasons among wetlands of Northern Region (Ghana). Intl J Ecol 2016: 1598701. DOI: $0.1155 / 2016 / 1598701$. 
Nuryanto A, Bhagawati D, Abulias MN, Indarmawan. 2012. Fish diversity at Cileumeuh River in District of Majenang, Cilacap Regency, Central Java. Jurnal Iktiologi Indonesia 12 (2): 147-153.

Nuryanto A, Bhagawati D, Abulias N, Indarmawan. 2016. Ichthyofauna at Cijalu river, Cilacap regency Central Java province, Indonesia. Biotropia 23 (1): 1-9.

Ohee HL. 2016. Freshwater fish diversity in an oil palm concession area in Mimika, Papua. Biodiversitas 17 (2): 665-672. DOI: 10.13057/biodiv/d170240

Pander J, Geist J. 2018. The contribution of different restored habitats to fish diversity and population development in a highly modified river: A case study from the River Günz. Water 10: 1202. DOI: $10.3390 / w$ 10091202

Paujiah E, Solihin DD, Affand R. 2019. Community structure of fish and environmental Characteristics in Cisadea river, West Java, Indonesia. Jurnal Biodjati 4 (2): 278-290.

Petsut N, Kulabtong S, Petsut J. 2017. Species diversity and distribution of fishes in Pranburi river, Phetchaburi province and Prachuap Khirikhan province. Intl J Agric Technol 13 (5): 671-682.
Rashid ZA, Asmuni M, Amal MNA. 2015. Fish diversity of Tembeling and Pahang rivers, Pahang Malaysia. J Biodivers Data 11 (5): 1753.

Ridho MR, Patriono E, Sholikah M. 2019. Food habits of three species of mudskippers in the Musi River Estuary, South Sumatra, Indonesia. Biodiversitas 20 (8): 2368-2374. DOI: 10.13057/biodiv/d200835

Stegmann LF, Leitão RP, Zuanon J, Magnusson WE. 2019. Distance to large rivers affects fish diversity patterns in highly dynamic streams of Central Amazonia. PLoS ONE 14 (10): e0223880. DOI: 10.1371/journal.pone.0223880.

Suryaningsih S, Sukmaningrum S, Simanjuntak SBI, Kusbiyanto. 2018. Diversity and longitudinal distribution of freshwater fish in Klawing River, Central Java, Indonesia. Biodiversitas 19 (1): 85-92. DOI: 10.13057/biodiv/d190114.

Tan M, Armbruster JW. 2018. Phylogenetic classification of extant genera of fishes of the order Cypriniformes (Teleostei: Ostariophysi). Zootaxa 4476 (1): 6-39.

Yagci A, Yagci M, Bilgin F, Erbatur I. 2016. The effects of physicochemical parameters on fish distribution in Egirdir Lake, Turkey. Iranian J Fish Sci 15 (2): 846-857. 